\title{
The influence of protein:energy value of the ration and level of feed intake on the energy and nitrogen metabolism of the growing pig
}

\section{Energy metabolism}

\author{
BY W. H. CLOSE, F. BERSCHAUER*† AND R. P. HEAVENS \\ ARC Institute of Animal Physiology, Babraham, Cambridge CB2 4AT
}

(Received 28 July 1982 - Accepted 22 October 1982)

\begin{abstract}
1. The heat losses and energy and nitrogen balances of thirty-six individually-housed, entire male pigs (initial body-weight $18-30 \mathrm{~kg}$ ) were measured over $7 \mathrm{~d}$ periods, when they were fed on rations containing 153, 201 and $258 \mathrm{~g}$ crude protein (nitrogen $\times 6.25 ; \mathrm{CP}) / \mathrm{kg}$ dry matter (DM). The rations also contained $16 \cdot 29,16.96$ and $17 \cdot 24 \mathrm{MJ}$ metabolizable energy (ME) $/ \mathrm{kg}$ DM so that the CP: ME values were $9 \cdot 4,11.8$ and $15.0 \mathrm{~g} \mathrm{CP} / \mathrm{MJ}$ ME respectively. Each ration was given at three levels, 20,35 and $50 \mathrm{~g}$ feed $/ \mathrm{kg}$ body-weight per $\mathrm{d}$, thus giving nine dietary treatments. The experiments were carried out at an environmental temperature of $22( \pm 1)^{\circ}$.

2. Heat loss $(H)$ increased significantly $(P<0.01)$ with increase in $\mathrm{ME}$ intake. The rate of increase in $H$ was not, however, influenced by the protein content of the ration. Thus, energy retention (ER) at any given level of ME intake was independent of the ration offered. From the relationship between ER and ME, estimates of the maintenance energy requirement $\left(\mathrm{ME}_{\mathrm{m}}\right)$ and the partial efficiency of energy utilization $(k)$ were determined. $\mathrm{ME}_{\mathrm{m}}$ varied within the range $494-568 \mathrm{~kJ} / \mathrm{kg}$ body-weight ${ }^{0} 75$ per d, while $k$ varied from 0.70 to 0.76 .

3. Both energy and protein intakes had a significant influence upon the rates of protein $(P)$ and fat $(F)$ deposition, and hence body-weight gain. At any given level of feed intake $P$ was higher and $F$ lower the higher the protein content of the ration. However, when compared at similar levels of protein intake, both $P$ and $F$ were reduced the higher the protein content of the ration.

4. From the multiple regression equations relating $P$ and $F$ to $\mathrm{ME}$, individual estimates of $\mathrm{ME}_{m}$ and the energetic efficiencies of protein $\left(k_{P}\right)$ and fat $\left(k_{F}\right)$ depositions were determined. Using an overall mean $k_{F}$ value of $0 \cdot 86$, it was calculated that $\mathrm{ME}_{\mathrm{m}}$ ranged from 462 to $525 \mathrm{~kJ} / \mathrm{kg}$ body-weight ${ }^{0.75}$ per $\mathrm{d}$ while $k_{P}$ varied from 0.48 to 0.55 . The significance of these estimates of $k_{P}$ are discussed in the light of their derivations and in relation to theoretical values.
\end{abstract}

In assessing the energy requirements of farm animals it has been customary to partition the metabolizable energy $(\mathrm{ME})$ intake into that required for maintenance $\left(\mathrm{ME}_{\mathrm{m}}\right)$ and that for production $\left(\mathrm{ME}_{\mathrm{p}}\right)$. The productive component can be further partitioned into a requirement for protein deposition and a requirement for fat deposition. This procedure allows separate estimates for the energetic efficiency of protein $\left(k_{P}\right)$ and fat $\left(k_{F}\right)$ deposition to be calculated. Estimates of $\mathrm{ME}_{\mathrm{m}}, k_{P}$ and $k_{F}$ are usually calculated from regression analyses where $\mathrm{ME}$ or $\mathbf{M E}_{P}$ is related to the quantities of protein and fat deposited. Using these techniques it has been found in the pig, maintained under thermally-neutral conditions, that while values for $k_{F}$ remain relatively constant and close to those calculated on theoretical grounds, those for both $\mathrm{ME}_{\mathrm{m}}$ and $k_{P}$ vary considerably, the latter being generally lower than theoretical calculations indicate (Kielanowski, 1976; Pullar \& Webster, 1977; Close, 1978; Fowler et al. 1980; Mount, 1980; Webster, 1980). These authors have proposed various hypotheses for the variation in $k_{p}$. These include differences associated with technique, variation in body-weight with heavier animals having lower efficiencies, differences in the method of calculation, the use of an inappropriate coefficient for metabolic body size, the extent of interdependence of the variables under investigation and the extent of protein turnover. There

* On leave from Institut für Tierernährung der Universität Hohenheim, 7 Stuttgart 70, Federal Republic of Germany.

† Present address: Bayer AG, Institut für Chemotherapie, Pharmaforschungszentrum, 5600 Wuppertal 1, Federal Republic of Germany. 
exists the possibility, however, that part of the variation may be associated with differences in the level and type of feed ingredients used for the provision of the dietary nutrients. Thus for the young pig, where higher values of $\mathrm{ME}_{\mathrm{m}}$ and $k_{P}$ have been calculated (Kielanowski, 1965; Hoffman et al. 1977; Close \& Stanier, 1980), dietary nutrients are provided in a more-readily-available form so that the protein and ME concentrations of the diets are usually higher than those for the growing or mature animal. Theoretical calculations based on the composition of the energy and protein fractions would also indicate this to be the situation (Agricultural Research Council/Medical Research Council, 1974; Müller \& Kirchgessner, 1979). The question which arises, therefore, is whether differences in the relative concentrations of protein and energy in the feed influence the efficiency of protein and fat utilization in the pig. This problem has been investigated in the present experiments by determining the $\mathrm{ME}_{\mathrm{m}}$ and the $k_{P}$ and $k_{F}$ when young growing entire male pigs were fed on different concentrations of protein in the ration at constant concentrations of ME. A subsequent paper (Berschauer et al. 1983) describes aspects related to the nitrogen metabolism of the animals when they were exposed to two environmental temperatures. Part of this work has been the subject of a preliminary communication (Close \& Berschauer, 1981).

\section{MATERIAL AND METHODS}

\section{Animals}

The animals used in the present experiments were enzootic-pneumonia-free, entire male pigs of the Large White breed. After weaning at 6 weeks of age the animals were removed in groups of eight to temperature-controlled pens, maintained at $22( \pm 1)^{\circ}$. The animals remained here until selected for experiments at approximately 10 weeks of age. The body-weights of the animals at the beginning of the calorimetric studies ranged between 18 and $30 \mathrm{~kg}$, the variation being due to the different feeds and levels of feeding imposed upon the animals.

\section{Plan of experiments}

The experiments were designed in a $3 \times 3$ factorial arrangement involving three rations each of different protein concentrations with three feeding levels on each diet. There were, therefore, nine combinations of dietary protein concentration and feeding level (energy intake) and as four pigs were allocated to each treatment, this involved a total of thirty-six pigs. At each treatment the environmental temperature was maintained constant at 22 $( \pm 1)^{\circ}$, as this temperature was calculated to be within the animal's thermoneutral zone at each level of energy intake (Close \& Mount, 1978).

\section{Nutrition}

The rations were designed to supply three different protein concentrations of $150(\mathrm{~L}), 200$ (M) and $250(\mathrm{H}) \mathrm{g}$ crude protein $(\mathrm{N} \times 6.25 ; \mathrm{CP}) / \mathrm{kg}$ dry matter (DM). It was also intended that the energy concentration of each ration was constant at approximately $16.5 \mathrm{MJ} \mathrm{ME} / \mathrm{kg}$ DM. In practice the rations contained 153, 201 and $258 \mathrm{~g} \mathrm{CP} / \mathrm{kg}$ DM respectively, with corresponding ME contents of $16.29,16.96$ and $17.24 \mathrm{MJ} / \mathrm{kg} \mathrm{DM}$. The variation in the concentration of crude protein at similar ME content was achieved by varying the relative amounts of cereals, starch, soya bean, tallow, casein and wheat bran in the ration. The ingredient compositions and chemical analyses of the three rations are given in Tables 1 and 2 respectively.

The amino acid composition was similar for each ration as reported in Table 3 . Each ration was given at three different levels of intake: 20,35 and $50 \mathrm{~g}$ feed $/ \mathrm{kg}$ body-weight per d. On the basis that the animal's thermoneutral maintenance energy requirement is $440 \mathrm{~kJ}$ $\mathrm{ME} / \mathrm{kg}$ body-weight ${ }^{0.75}$ per $\mathrm{d}$ (Close, 1978), these were anticipated to correspond to intakes of $1.5,3.0$ and 4.5 times the thermoneutral $\mathrm{ME}_{\mathrm{m}}$ requirement. 
Table 1. Ingredient composition of the three rations $(\mathrm{g} / \mathrm{kg}$ diet $)$

\begin{tabular}{|c|c|c|c|}
\hline & \multicolumn{3}{|c|}{ Protein } \\
\hline & Low & Medium & High \\
\hline Barley & 92 & 135 & 177 \\
\hline Wheat & 104 & 152 & 200 \\
\hline Maize starch & 341 & 165 & - \\
\hline Soya bean & 120 & 165 & 210 \\
\hline Tallow & 60 & 100 & 140 \\
\hline Casein & 70 & 95 & 120 \\
\hline Wheat bran & 50 & 25 & - \\
\hline Molasses & 35 & 35 & 35 \\
\hline $\begin{array}{c}\text { Nutrimol }^{\circledR} \text { (cane molasses/ } \\
\text { brewers grain) }\end{array}$ & 80 & 80 & 80 \\
\hline $\begin{array}{c}\text { Curtexal }^{\circledR} \text { (ligno-sulphonate } \\
\text { (binding agent)) }\end{array}$ & 25 & 25 & 25 \\
\hline Limestone & 10 & 10 & 10 \\
\hline Salt & 5 & 5 & 5 \\
\hline Dicalcium phosphate & 5 & 5 & 5 \\
\hline Pig growers' premix* & 2.5 & $2 \cdot 5$ & $2 \cdot 5$ \\
\hline
\end{tabular}

* Dalgety Spillers Agriculture.

Table 2. Chemical composition of the three rations* $(\mathrm{g} / \mathrm{kg}$ dry matter (DM)) (Mean values with their standard errors, where given, in parentheses)

\begin{tabular}{|c|c|c|c|}
\hline & \multicolumn{3}{|c|}{ Protein } \\
\hline & Low & Medium & High \\
\hline $\mathrm{DM}(\mathrm{g} / \mathrm{kg})$ & 884 & 884 & 897 \\
\hline Crude protein (nitrogen $\times 6.25$ ) & 153 & 201 & 258 \\
\hline Crude fibre & 31 & 36 & 38 \\
\hline Diethyl ether extract & 66 & 103 & 144 \\
\hline Ash & 59 & 59 & 68 \\
\hline Silicon-free-ash & 54 & 54 & 58 \\
\hline $\mathrm{N}$-free-extract & 691 & 601 & 492 \\
\hline Calcium & 10 & 9 & 10 \\
\hline Magnesium & 1.5 & 1.5 & 1.5 \\
\hline Potassium & $7 \cdot 2$ & 7.8 & $7 \cdot 4$ \\
\hline Sodium & $2 \cdot 4$ & $2 \cdot 1$ & $2 \cdot 6$ \\
\hline Phosphorous & $4 \cdot 3$ & $4 \cdot 7$ & 4.5 \\
\hline Copper $(\mathrm{mg} / \mathrm{kg})$ & 183 & 176 & 197 \\
\hline $\operatorname{Zinc}(\mathrm{mg} / \mathrm{kg})$ & 119 & 121 & 139 \\
\hline Manganese (mg/kg) & 51 & 50 & 51 \\
\hline Gross energy (MJ/kg DM) & $19.98(0.07)$ & $20.11(0.03)$ & $20.92(0 \cdot 14)$ \\
\hline Digestible energy (MJ/kg DM) & $16.51(0.07)$ & $17 \cdot 20(0 \cdot 16)$ & $17.55(0.11)$ \\
\hline Metabolizable energy (MJ $/ \mathrm{kg}$ DM) & $16.29(0.10)$ & $16.96(0.16)$ & $17 \cdot 24(0 \cdot 12)$ \\
\hline
\end{tabular}

* For details, see Table 1.

The feed was prepared in pelleted form ( $5 \mathrm{~mm}$ diameter) and the animal's daily allowance was divided into equal quantities and given at 09.00 and 16.30 hours. The feed offered to the animals was adjusted three times each week, on the basis of the gain in body-weight between weighings expected from the animal's previous rate of gain. Any feed spilled or 
Table 3. The amino acid composition of the three rations*

(Values expressed as $\mathrm{g} / 16 \mathrm{~g}$ nitrogen)

\begin{tabular}{|c|c|c|c|}
\hline & \multicolumn{3}{|c|}{ Protein } \\
\hline & Low & Medium & High \\
\hline Lysine & $6 \cdot 2$ & $6 \cdot 2$ & $6 \cdot 1$ \\
\hline Methionine & $2 \cdot 0$ & $2 \cdot 0$ & $2 \cdot 0$ \\
\hline Cystine & $1 \cdot 4$ & $1 \cdot 3$ & 1.25 \\
\hline Threonine & 4.0 & $3 \cdot 9$ & $4 \cdot 0$ \\
\hline Tryptophan & 0.8 & 0.8 & 0.8 \\
\hline Isoleucine & $4 \cdot 8$ & $4 \cdot 8$ & $4 \cdot 9$ \\
\hline Leucine & $8 \cdot 3$ & $8 \cdot 2$ & $8 \cdot 3$ \\
\hline Histidine & $2 \cdot 8$ & $2 \cdot 7$ & $2 \cdot 8$ \\
\hline Phenylalanine & $5 \cdot 2$ & $5 \cdot 0$ & $5 \cdot 1$ \\
\hline Tyrosine & $4 \cdot 0$ & $4 \cdot 1$ & $4 \cdot 2$ \\
\hline Valine & $5 \cdot 8$ & $5 \cdot 8$ & 5.9 \\
\hline
\end{tabular}

* For details, see Table 1.

refused by the animals was collected, weighed, stored in a cold room and analysed at the end of each experiment. The animals had access to water $a d l i b$. and both feed and water were kept at an environmental temperature of $22^{\circ}$.

\section{Experimental routine}

In the controlled temperature pens the animals became habituated to the environmental temperature. In addition, both the type and level of feeding were adjusted to that of the particular experiment. In all there were nine groups of animals, one for each dietary treatment. At approximately 10 weeks of age, when the animals had become conditioned to the experimental conditions, four animals were removed from the group and placed in individual, mobile metabolism pens, where they remained for a $7 \mathrm{~d}$ period. This period served to habituate the animals to the conditions within the calorimeters and to the experimental protocol. Following habituation, each animal, in its mobile pen, was wheeled into the calorimeter where its heat loss and energy and $\mathrm{N}$ balance were recorded for a further $7 \mathrm{~d}$. The experimental period began on a Monday morning and, during the ensuing $7 \mathrm{~d}$ balance period, the metabolism pens were changed on a Wednesday and Friday morning, a process that was completed within $15 \mathrm{~min}$; at this time the animals were weighed and their rectal temperatures recorded.

Because of the nature of the investigation it was decided that all animals should have a similar age and body-weight when selected for the experiments at 6 weeks of age. The 5 -week period prior to the calorimetric and balance measurements served to habituate and condition the animals to the experimental treatments. Thus, at the beginning of the measurement period, each animal had been subjected to the respective treatment for a similar duration. In this way, and assuming that the animals had similar rates of metabolism and body composition when weaned at 6 weeks of age, the difference in the animal's response should be that associated with the dietary treatment imposed upon them. The present design, therefore, precluded the use of animals of similar body-weight during the period of observation, since this would have involved animals of different ages and body composition and hence different physiological states when they would have been suitably conditioned to the experimental treatments. Adoption of this approach would have made it difficult to separate the effects of the dietary treatments from those of the differing animal characteristics. 


\section{Measurements}

Heat loss $(H)$. The calorimeters used were of the direct, heat-sink type (Close \& Mount, 1975). Sensible and evaporative heat losses were recorded continuously throughout each $7 \mathrm{~d}$ period and calculated as the mean hourly rate within each $24 \mathrm{~h}$ period. The evaporative component of heat loss represented water loss from the pen as a whole, that is, from both the animal and the faeces and urine voided by the animal within the calorimeter. The mean relative humidity within the calorimeter was $60( \pm 3) \%$.

Energy balance. The collection, sampling and analysis of feed and excreta were similar to the procedures described by Close \& Mount (1978). The ME intake of the animals was calculated from the gross energy (GE) content of the feed and that of faeces, urine and methane, the last being calculated at $0.6 \%$ of the GE intake (Close \& Mount, 1978).

$N$ balance. The animal's $\mathrm{N}$ retention was calculated as the difference between the $\mathrm{N}$ intake in the feed and the $\mathrm{N}$ of the faeces and urine voided by the animal and the $\mathrm{N}$ generated as ammonia within the calorimeter. The latter was measured as previously described by Verstegen et al. (1973) and, as a percentage of $\mathrm{N}$ intake, varied within the range $0.6-1.8 \%$.

Derived quantities. From the difference between ME intake and $H$ the animal's energy retention (ER) was calculated. As ER is primarily protein and fat and, on the basis that the energy retained as crude protein $(N \times 6.25)$ is $23.8 \mathrm{~kJ} / \mathrm{g}$ (Brouwer, 1965), the energy retained as fat was calculated. The weight of fat was then calculated assuming an energy content of $39.8 \mathrm{~kJ} / \mathrm{g}$ (Brouwer, 1965).

\section{Statistical analysis}

The results of the experiments were statistically analysed using Student's $t$ test. In addition, regression analyses were performed.

\section{RESULTS}

Feed intake

No problems were experienced with the animals' acceptance of the three rations offered. However, the $50 \mathrm{~g} / \mathrm{kg}$ feeding level on the $\mathrm{H}$ ration was above the animal's ad lib intake. On this treatment, feed was available to appetite at all times and enough feed was provided to ensure that there were always feed refusals. The animal's ad lib. intake of this ration corresponded to a feeding level of $43 \mathrm{~g}$ feed $/ \mathrm{kg}$ body-weight per $\mathrm{d}$. In all other respects the animals performed normally as illustrated by the results of growth rate, water intake and rectal temperature presented in Table 4.

With all three rations the estimates of the digestibility and metabolizability of energy showed the same pattern of decrease with increase in feed intake. However the decreases were small, between 2 and $3 \%$, and not significant $(P>0.05)$. DE, as a proportion of ME, was also independent of the diet and level of feeding. The mean values for $\mathrm{DE} / \mathrm{GE}, \mathrm{ME} / \mathrm{GE}$ and ME/DE $( \pm S E)$ for all rations and levels of feeding were $0.855 \pm 0.002,0.842 \pm 0.002$ and $0.984 \pm 0.001$ respectively.

\section{The partition of $M E$}

The partition of the ME intake for all nine dietary combinations into the components of $H$, ER, $P$ and $F$ are given in Table 5 . The results have been expressed per kg body-weight ${ }^{0.75}$. Values for each individual animal have been calculated from its mean body-weight throughout the $7 \mathrm{~d}$ experimental period.

Heat loss. There was a significant $(P<0.01)$ increase in $H$ with increase in ME intake but the rate of increase was independent of the protein content of the ration, indicating that the differences were due to an increase in energy intake rather than an increase in protein intake. The increase in $H$ was associated with an increase in both its sensible and evaporative 


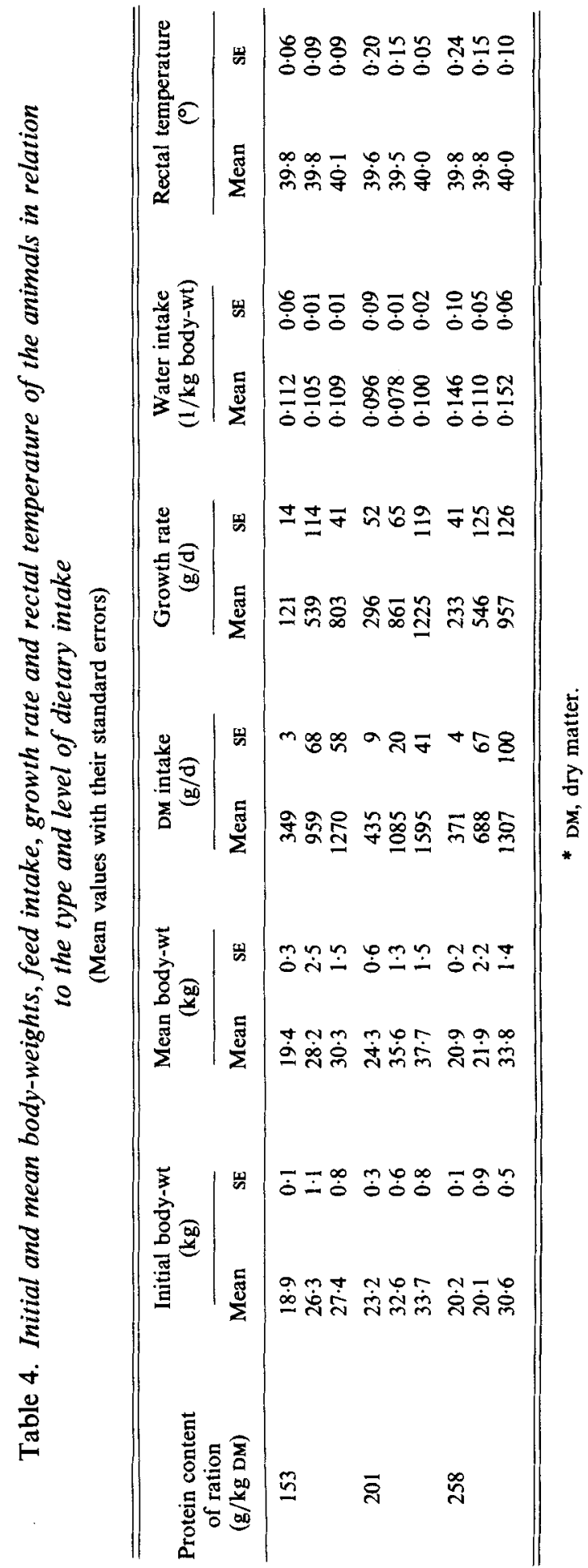


Table 5. Mean values ( $\mathrm{kJ} / \mathrm{kg}$ body-weight $t^{0.75}$ per d) for metabolizable energy (ME) intake, heat loss $(\mathrm{H})$, energy retention $(E R)$, protein $(\mathrm{P})$ and fat $(\mathrm{F})$ deposition for pigs on different levels of feeding and rations of different protein concentration

(Mean values with their standard errors)

\begin{tabular}{|c|c|c|c|c|c|c|c|c|c|c|}
\hline \multirow{2}{*}{$\begin{array}{l}\text { Protein content } \\
\text { of ration } \\
\text { (g/ } \mathbf{k g ~ D M ) ~}\end{array}$} & \multicolumn{2}{|c|}{ ME intake } & \multicolumn{2}{|c|}{$H$} & \multicolumn{2}{|c|}{ ER } & \multicolumn{2}{|c|}{$P$} & \multicolumn{2}{|c|}{$F$} \\
\hline & Mean & SE & Mean & $\mathrm{SE}$ & Mean & $\mathrm{SE}$ & Mean & SE & Mean & $\mathrm{SE}$ \\
\hline 153 & $\begin{array}{r}617 \\
1129 \\
1612\end{array}$ & $\begin{array}{r}4 \\
15 \\
10\end{array}$ & $\begin{array}{l}571 \\
647 \\
833\end{array}$ & $\begin{array}{l}12 \\
23 \\
37\end{array}$ & $\begin{array}{r}46 \\
482 \\
779\end{array}$ & $\begin{array}{l}10 \\
29 \\
45\end{array}$ & $\begin{array}{r}69 \\
151 \\
204\end{array}$ & $\begin{array}{r}3 \\
10 \\
15\end{array}$ & $\begin{array}{r}-23 \\
331 \\
575\end{array}$ & $\begin{array}{l}28 \\
55 \\
93\end{array}$ \\
\hline 201 & $\begin{array}{r}703 \\
1261 \\
1760\end{array}$ & $\begin{array}{r}6 \\
27 \\
21\end{array}$ & $\begin{array}{l}609 \\
714 \\
863\end{array}$ & $\begin{array}{l}24 \\
15 \\
10\end{array}$ & $\begin{array}{r}94 \\
547 \\
897\end{array}$ & $\begin{array}{l}27 \\
24 \\
20\end{array}$ & $\begin{array}{r}96 \\
186 \\
275\end{array}$ & $\begin{array}{r}7 \\
25 \\
27\end{array}$ & $\begin{array}{l}-2 \\
358 \\
633\end{array}$ & $\begin{array}{l}51 \\
36 \\
44\end{array}$ \\
\hline 258 & $\begin{array}{r}656 \\
1170 \\
1604\end{array}$ & $\begin{array}{r}7 \\
27 \\
35\end{array}$ & $\begin{array}{l}556 \\
676 \\
849\end{array}$ & $\begin{array}{l}19 \\
17 \\
33\end{array}$ & $\begin{array}{l}100 \\
494 \\
755\end{array}$ & $\begin{array}{l}14 \\
21 \\
51\end{array}$ & $\begin{array}{r}99 \\
191 \\
271\end{array}$ & $\begin{array}{l}23 \\
17 \\
21\end{array}$ & $\begin{array}{r}1 \\
303 \\
484\end{array}$ & $\begin{array}{l}49 \\
43 \\
83\end{array}$ \\
\hline
\end{tabular}

DM, dry matter.

components. The mean sensible $H$ at the three feeding levels were 423,501 and $660 \mathrm{~kJ} / \mathrm{kg}$ body-weight ${ }^{0.75}$ per $\mathrm{d}$; the corresponding values for evaporation were 156,169 and 243 respectively. Thus, while sensible $H$ increased with level of feed intake, that of evaporation was independent of the level of feeding at the two lower intakes. However, when expressed as a percentage of total $H$, evaporation remained relatively constant at each level of feeding and averaged $26 \cdot 9,25.9$ and $28.6 \%$ on the low, medium and high feed intakes respectively. This confirmed that the environmental temperature of $22^{\circ}$ was within the thermoneutral zone for the animals at all three levels of feeding.

Energy retention. Values of ER, calculated as the difference between ME intake and $H$, are shown in Table 5. The values for the individual experiments are plotted against ME intake in Fig. 1. There was a high correlation between ME intake and ER, the linear regression equations for the low-, medium- and high-protein rations respectively being:

M:

$$
y=0.74( \pm 0.04) x-394( \pm 51)
$$

$$
\text { ( } r \text { 0.98; residual mean square, } 3592 \text {; } \mathrm{df}=11 \text { ), }
$$

( $r$ 0.99; residual mean square, 1267 ; $\mathrm{d}=11$ ),

H:

$$
y=0.70( \pm 0.04) x-346( \pm 45)
$$

All values:

$$
\text { ( } r \text { 0.99; residual mean square, } 2569 \text {; } \mathrm{df}=11 \text { ), }
$$

$$
\text { ( } r \text { 0.99; residual mean square, 2344; } \mathrm{df}=35 \text { ), }
$$

where $y=\mathrm{ER}$ and $x=$ ME intake, expressed in $\mathrm{kJ} / \mathrm{kg}$ body-weight $\mathrm{t}^{0.75}$ per $\mathrm{d}$. The coefficients of $x$, that is the efficiencies of energy utilization, were not significantly $(P>0.05)$ influenced by the rations offered to the animals.

Estimates of the maintenance energy requirement, the $M E$ intake at which $E R=0$, were calculated from eqns (1)-(3) to be $532(\mathrm{~L}), 568(\mathrm{M})$ and $494(\mathrm{H}) \mathrm{kJ} / \mathrm{kg}$ body-weight ${ }^{0.75}$ per $\mathrm{d}$. The overall mean value, calculated from eqn (4), was $536 \mathrm{~kJ} / \mathrm{kg}$ body-weight $\mathrm{t}^{0.75}$ per d. Protein deposition. The mean rates of $P$ for each combination of ME intake and protein 

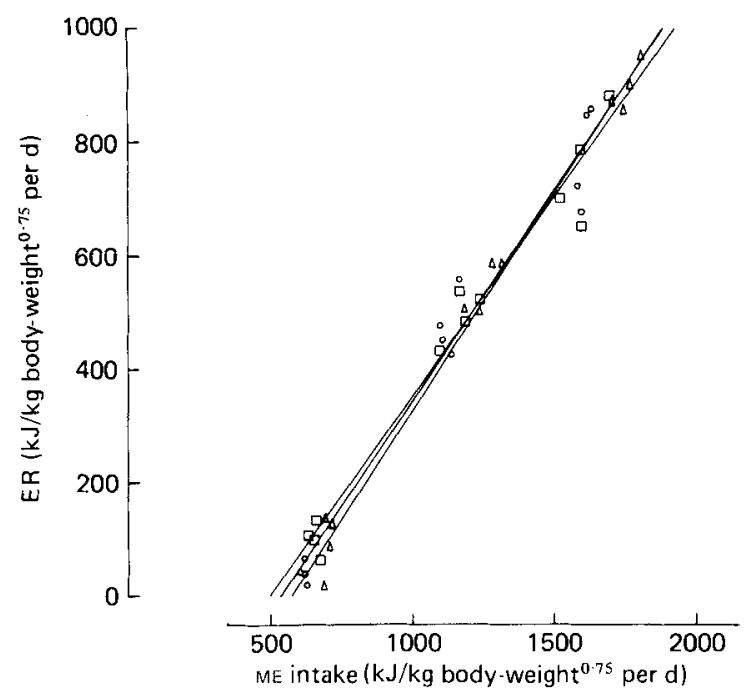

Fig. 1. The relation between energy retention $\left(\mathrm{kJ} / \mathrm{kg}\right.$ body-weight $\mathrm{t}^{\mathbf{0 7 5}}$ per $\mathrm{d}$; ER) and metabolizable energy (ME) intake $\left(\mathrm{kJ} / \mathrm{kg}\right.$ body-weight ${ }^{0 \cdot 75}$ per d) for pigs fed on rations differing in protein : energy. $(\mathrm{O})$, Low-protein ration $(9.4 \mathrm{~g}$ crude protein (nitrogen $\times 6.25 ; \mathrm{CP}) / \mathrm{MJ} \mathrm{ME}) ;(\triangle)$, medium-protein ration (11.8 g CP/MJ ME); ( $\square$ ), high-protein ration (15.0 g CP/MJ ME).

intake (IP) are given in Table 5. $P$ increased with both the level of feeding and the protein content of the ration. To examine the influence of ME intake and IP on $P$, a regression analysis was carried out for all dietary combinations. The equation $( \pm \mathrm{SE})$ was:

$$
\begin{gathered}
P=-27.0( \pm 18.0)+0.0660( \pm 0.018) \mathrm{ME}+0.4302( \pm 0.155) \mathrm{IP}-0.000176 \\
( \pm 0.00016)(\mathrm{IP})^{2} \\
(r 0.94 ; \text { residual mean square } 343 ; \mathrm{df}=35),
\end{gathered}
$$

where $P$, ME intake and IP are in $\mathrm{kJ} / \mathrm{kg}$ body-weight ${ }^{0.75}$ per $\mathrm{d}$. Both ME intake and IP had a significant influence $(P<0.01)$ on $P$, while that of $(\mathrm{IP})^{2}$ was non-significant $(P>0.05)$. However, since $P$ has been shown to be related to IP in a quadratic manner, the term (IP) ${ }^{2}$ has been included in the analysis. From eqn (5), it can be seen that the largest effect on $P$ was that of IP, with ME intake exhibiting a smaller, yet significant effect. The intercept term, $-27.0 \mathrm{~kJ} / \mathrm{kg}$ body-weight $\mathrm{t}^{0.75}$ per $\mathrm{d}$, that is, $-0.18 \mathrm{~g} \mathrm{~N} / \mathrm{kg}$ body-weight ${ }^{0.75}$ per $\mathrm{d}$, represents fasting $\mathrm{N}$ metabolism and compares with the value of $-0.23 \mathrm{~g} \mathrm{~N} / \mathrm{kg}$ bodyweight $^{0.75}$ per d proposed by Gebhardt \& Müller (1971), Berschauer (1977) and Menke (1979).

Values of $P$ derived from eqn (5) and calculated in relation to ME intake are presented in Fig. 2 for the three rations. It is interesting to determine to what extent changes in both ME intake and IP influence $P$. Thus eqn (5) indicated that the rate of change of $P$ to an incremental change in ME intake, that is $\mathrm{d} P / \mathrm{dME}$, was independent of protein intake, being constant at $0.066 \mathrm{~kJ} / \mathrm{kJ}$ increase in ME intake (Table 6). On the other hand the rate at which $P$ increased per unit increase in IP, that is the efficiency of protein utilization, decreased with increase in feeding level:

$$
\frac{\mathrm{d} P}{\mathrm{dIP}}=0.4302-0.000352 \mathrm{IP}
$$

Since low levels of IP were associated with low intakes of ME, $d P / d I P$ was higher at the low ME intakes and decreased from a mean value of 0.37 at an intake of $600 \mathrm{~kJ} \mathrm{ME} / \mathrm{kg}$ 


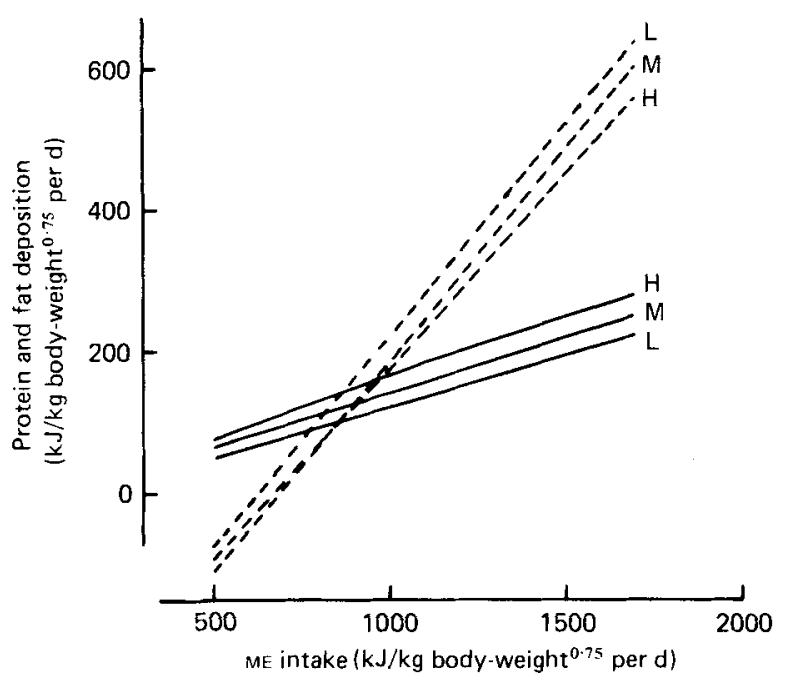

Fig. 2. The relation between protein $\left(\mathrm{kJ} / \mathrm{kg}\right.$ body-weight $\mathrm{t}^{0.75}$ per $\mathrm{d}$; - - ) and fat deposition $(\mathrm{kJ} / \mathrm{kg}$ body-weight ${ }^{0.75}$ per $\mathrm{d} ;$ - ...-.-) and metabolizable energy (ME) intake (kJ/kg body-weight ${ }^{0.75}$ per d) for pigs fed on rations differing in protein: energy. $\mathrm{L}$ (low-protein ration; $9.4 \mathrm{~g}$ crude protein (nitrogen $\times 6.25$; CP)/MJ ME); M (medium-protein ration; $11.8 \mathrm{~g} \mathrm{CP} / \mathrm{MJ} \mathrm{ME}$ ); $\mathrm{H}$ (high-protein ration; $15.0 \mathrm{~g} \mathrm{CP} / \mathrm{MJ} \mathrm{ME}$ ).

Table 6. The rate of increase in protein and fat deposition ( $k J / k J$ metabolizable energy $(M E)$ ) and body-weight gain $(\mathrm{g} / \mathrm{kJ} \mathrm{ME})$ per unit increment in ME intake at several rates of protein intake $\left(\mathrm{kJ} / \mathrm{kg}\right.$ body-weight $t^{0.75}$ per $\left.\mathrm{d}\right)$

(Values derived from eqns (5) and (7) (for details see pp. 262 and 264). Values are mean rates)

\begin{tabular}{cccc}
\hline & $\begin{array}{c}\text { Protein } \\
\text { deposition }\end{array}$ & $\begin{array}{c}\text { Fat } \\
\text { deposition }\end{array}$ & Body-wt gain \\
\hline 238 & 0.066 & 0.62 & 0.033 \\
357 & 0.066 & 0.66 & 0.033 \\
476 & 0.066 & 0.68 & 0.033 \\
\hline
\end{tabular}

body-weight $\mathrm{t}^{0.75}$ per d to 0.32 and 0.27 at intakes of 1100 and $1600 \mathrm{~kJ}$ ME $/ \mathrm{kg}$ body-weight $\mathrm{t}^{0.75}$ per d respectively (Table 7 ).

Fat deposition. The actual values of $F$, determined from the difference between ER and $P$, are shown in Table 5 for each combination of ME intake and IP. The values of $F$ presented in Fig. 2 are those derived from eqns (1)-(3) and the values of $P$ at the different intakes of ME and IP calculated from eqn (5). Fig. 2 illustrates that $F$ increased with the level of feeding. However, at any given ME intake the higher the protein content of the ration the lower the value of $F$. Correspondingly, there were differences in the rates at which $F$ changed per unit increment in ME intake $(\mathrm{d} F / \mathrm{dME})$ and $\mathrm{IP}(\mathrm{d} F / \mathrm{dIP})$ and these are compared with the corresponding values for $P$ in Tables 6 and 7 .

The changes in $P$ and $F$ with both ME intake and IP reflected variations in the composition of ER. At the medium levels of feeding the ratio $P$ : ER increased from 0.33 to 0.44 with increase in protein content of the ration. The corresponding values at the highest level of feeding were 0.27 and 0.34 . Thus $P$ made the highest contribution to ER at the medium feeding level on the high-protein ration. 
Table 7. The rate of increase in protein and fat deposition ( $k J / k J$ protein intake) and body-weight gain $(\mathrm{g} / \mathrm{kJ}$ protein intake) per unit increase in protein intake at several levels of metabolizable energy (ME) intake ( $k J / k g$ body-weight $t^{0.75}$ per d)

(Values derived from eqns (5) and (7) (for details see pp. 262 and 264). Values are mean rates)

\begin{tabular}{cccc}
\hline ME intake & $\begin{array}{c}\text { Protein } \\
\text { deposition }\end{array}$ & $\begin{array}{c}\text { Fat } \\
\text { deposition }\end{array}$ & Body-wt gain \\
\hline 600 & 0.37 & -0.06 & 0.11 \\
1100 & 0.32 & -0.30 & 0.07 \\
1600 & 0.27 & -0.34 & 0.03 \\
\hline
\end{tabular}

Body-weight gain $(\mathrm{G})$

As with $P, G\left(\mathrm{~g} / \mathrm{kg}\right.$ body-weight ${ }^{0 \cdot 75}$ per $\left.\mathrm{d}\right)$ was subjected to a multiple regression analysis with ME intake and IP as the dependent variables. The equation was:

$$
\begin{gathered}
G=-24.9( \pm 6.0)+0.03278( \pm 0.006) \mathrm{ME}+0.1624( \pm 0.051) \mathrm{IP}-0.000149 \\
( \pm 0.00005)(\mathrm{IP})^{2} \\
(r 0.93 ; \text { residual mean square } 38 ; \mathrm{df}=35) .
\end{gathered}
$$

where ME intake and IP are in $\mathrm{kJ} / \mathrm{kg}$ body-weight ${ }^{0.75}$ per $\mathrm{d}$.

The intercept term and the regression coefficients differed significantly from zero $(P<0 \cdot 01)$. Values of $G$ derived from eqn $(7)$ and calculated in relation to ME intake are presented in Fig. 3 for the three rations of differing protein:energy values $(9 \cdot 4,11.8$ and $15.0 \mathrm{~g} \mathrm{CP} / \mathrm{MJ} \mathrm{ME}$ ). An increase in ME intake resulted in an increase in $G$. However, at any given ME intake, $G$ was higher the higher the protein :energy value of the ration, as a result of the higher IP. When compared at similar levels of IP, $G$ was higher the lower the protein content of the ration since ME intake was higher at any given level of IP.

As with $P$ and $F$, the rate at which $G$ changed with change in ME was independent of IP (Table 6). The change in $G$ resulting from an incremental change in IP decreased with increase in IP as follows:

$$
\frac{\mathrm{d} G}{\mathrm{dIP}}=0 \cdot 1624-0 \cdot 000298 \mathrm{IP} .
$$

Thus the incremental change in $G$ was greater at the lower IPs and hence at the lower ME intakes (Table 7).

\section{DISCUSSION}

Protein and fat deposition

The results of the present investigation indicate that both $P$ and $F$ increased with increase in level of feed intake, but that $P$ was higher and $F$ lower the greater the protein concentration in the ration. These interactions are in accordance with the results of previous investigations (Blair et al. 1969; Cooke et al. 1972; Kellner \& Kirchgessner, 1973; Gray \& McCracken, 1974; Fuller et al. 1976; Braude et al. 1977; Campbell, 1977; Cromwell et al. 1978; McCracken et al. 1980). However, at similar rates of protein intake, $P$ was greater the lower the protein content of the ration in association with a higher ME intake and an increase in the efficiency of protein utilization (Berschauer et al. 1983). Thus at a protein intake of $15 \mathrm{~g} / \mathrm{kg}$ body-weight ${ }^{0.75}$ per $\mathrm{d}$, it was calculated that as the CP:ME content of the ration increased from $9 \cdot 4$ to 11.8 and $15.0 \mathrm{~g} / \mathrm{MJ}, P$ decreased from 210 to 188 and $170 \mathrm{~kJ} / \mathrm{kg}$ body-weight ${ }^{0.75}$ per $\mathrm{d}$. 


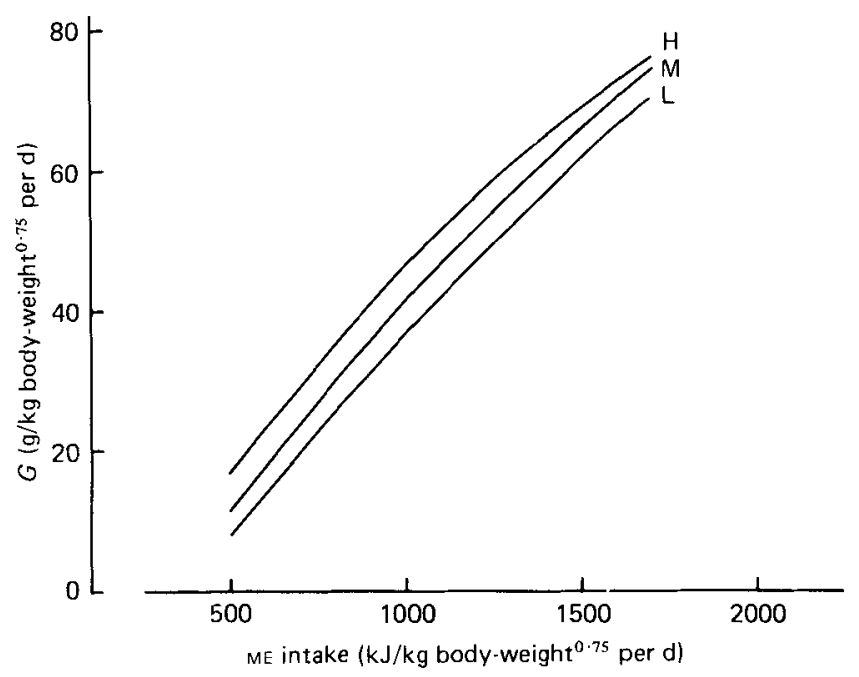

Fig. 3. The relation between body-weight gain $\left(\mathrm{g} / \mathrm{kg}\right.$ body-weight ${ }^{0 \cdot 75}$ per $\left.\mathrm{d} ; G\right)$ and metabolizable energy (ME) intake ( $\mathrm{kJ} / \mathrm{kg}$ body-weight ${ }^{0 \cdot 75}$ per d) for pigs fed on rations differing in protein : energy. L (low-protein ration; $9.4 \mathrm{~g}$ crude protein (nitrogen $\times 6.25 ; \mathrm{CP}$ ) $/ \mathrm{MJ} \mathrm{ME}$ ); $\mathrm{M}$ (medium-protein ration; $11.8 \mathrm{~g} \mathrm{CP} / \mathrm{MJ} \mathrm{ME}$ ); $\mathrm{H}$ (high-protein ration; $15.0 \mathrm{~g} \mathrm{CP} / \mathrm{MJ} \mathrm{ME}$ ).

There were also changes in the rate of change of $P$ and $F$ which were dependent upon the protein :energy relationship. However, the rates of change were more dependent on an incremental change in IP than in ME intake. Increasing the level of feed intake resulted in reductions in the rates of change of $P$ and $F(\mathrm{~kJ} / \mathrm{kJ})$ per unit increment in protein intake. However, the diminution of the effect was greater for $P$ and suggested that the relationship was curvilinear although no maximum was apparently attained, even though the animals on the high-protein ration were eating ad lib. From the calculations of Gebhardt \& Müller (1971) and Carr et al. (1977) it might have been anticipated that for a $30 \mathrm{~kg}$ pig (mean body-weight of the animals in the present experiment) maximum protein deposition would be 227 or $190 \mathrm{~kJ}$ protein $/ \mathrm{kg}$ body-weight ${ }^{0.75}$ per $\mathrm{d}$, respectively. This was close to the level attained by the animals on the low-protein ration, but below that of $271 \mathrm{~kJ}$ protein $/ \mathrm{kg}$ body-weight ${ }^{0.75}$ per $\mathrm{d}$ deposited by the animals fed ad lib. on the high-protein ration. However, differences in the capacity of the animal for protein retention depends not only on the availability, pattern and extent of utilization of protein and energy in the ration, but also on the weight of the animal (Oslage et al. 1966; Thorbek, 1975), its breed and sex (Piatkowski \& Jung, 1966; Nielsen, 1971; Sharma et al. 1971) and the environmental conditions to which it is exposed (Fuller \& Boyne, 1971; Close et al. 1978). These factors may have also contributed to the high rates of protein deposition attained in the present experiments.

\section{Body-weight gain}

An animal's body-weight gain can be modified by changes in both protein and energy intake. However, the response due to a change in IP is greater than that of ME intake, since the increase in lean gain, that is protein and its associated water, resulting from an increase in IP is two- or three-fold greater than the increase in fat as a result of an equivalent increase in ME intake. However, the beneficial effect of an increase in IP is only apparent when there is sufficient energy available. Conversely the beneficial effect of an increase in energy intake can be prevented or modified by an inadequate protein supply (Munro, 1964). 
The changes in the chemical composition of $G$ in relation to variations in both protein and energy intakes have been calculated on the basis that gut-fill and ash represent $10 \%$ of the gain (Verstegen et al. 1973) with the remainder comprising protein, water and fat. These calculations showed that although the water content increased with rate of gain, when expressed relative to total gain it decreased from 0.75 at the low feed intake to 0.56 on the high feed intake. The protein content of the ration did not influence these ratios. There was also little difference in the protein : lean (protein + water) values between treatments, with a mean value of 0.20 . This is in agreement with the value of 0.22 calculated by the Agricultural Research Council (1981). The contributions to total gain made by the fat and fat-free components are illustrated in Fig. 4. This shows that the quadratic response in $G$ with increase in ME intake was chiefly associated with the gain in lean tissue, that is protein and water. Fat gain responded in an essentially linear manner, suggesting that it is the pattern of lean tissue deposition which results in the diminishing increase in $G$ with increase in energy intake. These associations resulted in the energy required to deposit $1 \mathrm{~kg}$ lean meat decreasing with increase in the protein content of the ration. At an ME intake of $1100 \mathrm{~kJ}$ $\mathrm{ME} / \mathrm{kg}$ body-weight $\mathrm{t}^{0.75}$ per $\mathrm{d}$, the energy requirement per $\mathrm{kg}$ lean deposition decreased from $35.7 \mathrm{MJ}$ on the low-protein ration to 30.2 and $27 \cdot 1$ on the medium- and high-protein rations respectively.

\section{The efficiency of energy utilization}

From the results of the linear regression equations relating ER to ME intake, estimates of $\mathrm{ME}_{\mathrm{m}}$ and $k$ were calculated. Variations in $\mathrm{ME}_{\mathrm{m}}$ between 494 and $568 \mathrm{~kJ} / \mathrm{kg}$ body-weight $\mathrm{t}^{\mathrm{0} \cdot 75}$ per $\mathrm{d}$ and in $k$ between 0.70 and 0.76 were calculated for the rations of differing protein content. While the values of $k$ agree with other estimates made on pigs within the zone of thermal neutrality (Fuller \& Boyne, 1971; Verstegen et al. 1973; Close, 1978), the estimates of $\mathrm{ME}_{\mathrm{m}}$ are higher than those previously determined in this laboratory for castrated male pigs over a similar weight range; 418 (Verstegen et al. 1973) and $440 \mathrm{~kJ} / \mathrm{kg}$ body-weight ${ }^{0 \cdot 75}$ per $\mathrm{d}$ (Close, 1978). Although little documentation exists it is possible that entire male animals may have higher values of $\mathrm{ME}_{\mathrm{m}}$ than castrated animals in association with a higher body protein content and hence an enhanced rate of protein turnover. Nevertheless, the present values of $\mathrm{ME}_{\mathrm{m}}$ are within the range of estimates presented by Fowler et al. (1980).

The adequacy of calculating $k$ and $\mathrm{ME}_{\mathrm{m}}$ from linear regression analyses has been questioned (Agricultural Research Council, 1981), since a constant $k$ does not reflect the composition of the energy retained or the efficiencies with which the protein and fat components of that retention are deposited. Similarly the calculation of $\mathrm{ME}_{\mathrm{m}}$ at $\mathrm{ER}=0$, does not necessarily reflect the intake at which both $P$ and $F$ are zero (Fig. 2). An alternative approach to calculating the energy requirements for growth is to follow the approach adopted by Kielanowski (1965) where multiple-regression techniques are used with ME intake as the dependent variable and $P$ and $F$ as the independent variables. This approach allows theoretical estimates of $\mathrm{ME}_{m}$ to be calculated when there is no gain or loss of protein and fat, and, in addition, estimates separately the energetic efficiencies of $P$ and $F$. Thus all three components can be considered simultaneously. This approach has been used in the present study and the results of the equations relating ME intake $\left(y ; \mathrm{kJ} / \mathrm{kg}\right.$ body-weight ${ }^{0.75}$ per d) to $P\left(x_{1} ; \mathrm{kJ} / \mathrm{kg}\right.$ body-weight ${ }^{0 \cdot 75}$ per d) and $F\left(x_{2} ; \mathrm{kJ} / \mathrm{kg}\right.$ body-weight $^{0 \cdot 75}$ per d), together with the standard errors associated with their estimates, were:

$$
\begin{array}{lll}
\mathrm{L}: & y=356( \pm 107)+3.71( \pm 1.33) x_{1}+0.78( \pm 0.30) x_{2} & (r 0.98), \\
\mathrm{M}: & y=525( \pm 87)+1.82( \pm 0.84) x_{1}+1.15( \pm 0.24) x_{2} & (r 0.99), \\
\mathrm{H}: & y=503( \pm 68)+1.52( \pm 0.60) x_{1}+1.35( \pm 0.21) x_{2} & (r 0.98), \\
\text { All values: } & y=511( \pm 34)+1.74( \pm 0.31) x_{1}+1.22( \pm 0.09) x_{2} & (r 0.99) .
\end{array}
$$




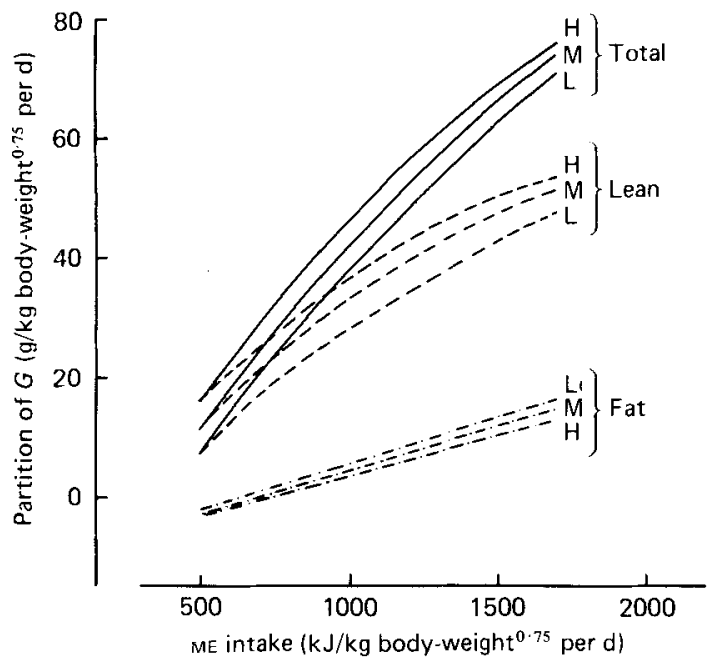

Fig. 4. The contribution made by lean (protein and its associated water; $\mathrm{g} / \mathrm{kg}$ body-weight $\mathrm{t}^{0.75}$ per $\mathrm{d}$; -...-) and fat $\left(\mathrm{g} / \mathrm{kg}\right.$ body-weight ${ }^{0^{* 75}}$ per $\left.\mathrm{d} ;-. . .-.\right)$ ) to total body-weight gain ( $\mathrm{g} / \mathrm{kg}$ body-weight $\mathrm{t}^{075}$ per $\mathrm{d} ; G ;-)$ in relation to metabolizable energy (ME) intake $\left(\mathrm{kJ} / \mathrm{kg}\right.$ body-weight ${ }^{0.75}$ per d) for pigs fed on rations differing in protein : energy. $\mathrm{L}$ (low-protein ration; $9.4 \mathrm{~g}$ crude protein (nitrogen $\times 6.25$; (CP)/MJ ME); $\mathrm{M}$ (medium-protein ration; $11.8 \mathrm{~g} \mathrm{CP} / \mathrm{MJ} \mathrm{ME}$ ); $\mathrm{H}$ (high-protein ration; $15.0 \mathrm{~g} \mathrm{CP/MJ} \mathrm{ME).}$

The reciprocals of the coefficients of $x_{1}$ and $x_{2}$ represent estimates of $k_{P}$ and $k_{F}$, while the intercept term is an estimate of $\mathrm{ME}_{\mathrm{m}}$.

There was little difference between the $M$ and $H$ rations in the estimates of $\mathrm{ME}_{\mathrm{m}}, 525$ and $503 \mathrm{~kJ} / \mathrm{kg}$ body-weight $\mathrm{t}^{0.75}$ per $\mathrm{d}, k_{P}, 0.55$ and 0.66 , and $k_{F}, 0.87$ and 0.74 respectively. There was also little difference between these values and those calculated when the results from all rations were combined; $\mathrm{ME}_{\mathrm{m}}=511 \mathrm{~kJ} / \mathrm{kg}$ body-weight $\mathrm{t}^{0.75}$ per $\mathrm{d}, k_{P}=0.57$ and $k_{F}=0.82$. This was in contrast to the estimates on the low-protein ration which indicated low values of $\mathrm{ME}_{\mathrm{m}}$ and $k_{P}, 365 \mathrm{~kJ} / \mathrm{kg}$ body-weight ${ }^{0.75}$ per $\mathrm{d}$ and 0.27 respectively, and a $k_{F}$ value of 1.28 which is theoretically impossible since it implies that the cost of retaining $1 \mathrm{~kJ}$ fat is only $0.78 \mathrm{~kJ}$. It is, however, interesting to observe that high values of $k_{F}$ are associated with low values of $k_{P}$ and $\mathrm{ME}_{\mathrm{m}}$ and vice versa. Since it has been shown that $k_{F}$ does not appear to vary substantially over a wide range of conditions (Agricultural Research Council, 1981), an alternate procedure to calculate the energy costs of growth is to compute a common coefficient of $F$ for all three rations and, using this value, to calculate separate values for the coefficient of $P$ and the intercept. The ensuing equations $( \pm \mathrm{SE})$ were:

L:

$$
\begin{aligned}
& y=484( \pm 69)+2.09( \pm 0 \cdot 71) x_{1}+1 \cdot 16( \pm 0 \cdot 14) x_{2}, \\
& y=525( \pm 66)+1.81( \pm 0 \cdot 53) x_{1}+1 \cdot 16( \pm 0 \cdot 14) x_{2}, \\
& y=462( \pm 60)+2.01( \pm 0.44) x_{1}+1 \cdot 16( \pm 0 \cdot 14) x_{2},
\end{aligned}
$$

where $y=$ ME intake, $x_{1}=P$ and $x_{2}=F$ in $\mathrm{kJ} / \mathrm{kg}$ body-weight ${ }^{0.75}$ per d.

When $k_{F}$ was maintained constant, there was little difference in the values of $k_{P}, 0.48$ to 0.55 , and $\mathrm{ME}_{\mathrm{m}}, 462$ to $525 \mathrm{~kJ} / \mathrm{kg}$ body-weight $\mathrm{t}^{0.75}$ per d, irrespective of the ration offered to the animals. The estimates of $\mathrm{ME}_{\mathrm{m}}$ are, in addition, in agreement with those calculated from the linear regression analysis. While the estimate of $k_{F}$ is in accordance with that calculated on theoretical grounds (Schiemann et al. 1961; Blaxter, 1962; Armstrong, 1969; Millward et al. 1976) it is higher than that of 0.74 calculated by the Agricultural Research Council (1981) as the preferred value for pigs within the weight range $20-100 \mathrm{~kg}$. The preferred value of $k_{P}$ calculated by the Agricultural Research Council (1981) was 0.56, which is in agreement 
with those values derived from the present study. These estimates of $k_{P}$ are less than those of 0.75 to 0.94 calculated on theoretical grounds (Schiemann et al. 1961; Blaxter, 1962; Armstrong, 1969; Millward et al. 1976). The usual explanation for this difference has been based on the suggestion that since protein synthesis greatly exceeds protein deposition, the energy cost of protein turnover requires a considerable amount of energy. However, recent evidence by Reeds et al. (1980) suggests that protein turnover alone cannot account for all the difference, suggesting that other processes may be involved which can contribute a significant proportion of the energy requirements for protein deposition.

The present results indicate that irrespecitive of the rations offered the energetic efficiency of growth is constant. It has been suggested that the net efficiency of energy retention may be dependent upon the chemical composition of the ration. Thus Millward et al. (1976) calculated a net efficiency of 0.86 for the conversion of carbohydrate into fat and suggested that the value would be higher if the diet contained fat and lower if the protein content was higher or if less protein was retained. Similarly, values determined by Schiemann et al. (1961) indicated that energy from dietary fat was incorporated into accreted fat with an efficiency of 0.86 , while the efficiencies with which dietary carbohydrate and protein were utilized were 0.76 and 0.66 respectively. It is, however, difficult to reconcile theoretical calculations with values determined in practice. Theoretical calculations presuppose an ideal dietary supply for tissue synthesis where all nutrients are assumed to be in their correct proportion. In addition no allowance is made for the energy cost of synthesizing non-essential nutrients or for the catabolism of nutrients surplus to requirements, as may occur under normal feeding practice and which can be utilized as sources of energy.

In the present experiments the maintenance of iso-energetic rations at the differing protein concentrations was achieved through variations in the fat and carbohydrate fractions. At any given level of energy intake the animals on the high-protein ration therefore consumed more protein (and amino acids) and fat, but less carbohydrate, relative to those animals on the low-protein diet. On the basis of theoretical calculations, a higher value of $k_{P}$ and $k_{F}$ would therefore have been anticipated.

The variations in $\mathrm{ME}_{\mathrm{m}} k_{P}$ and $k_{F}$ in relation to dietary treatment, discussed previously, are at best approximations since they are derived from statistical procedures. No statistical analysis can adequately reflect the physiological and biological processes occurring within the animal. There is, in addition, a degree of interdependence amongst the variables which makes it difficult to estimate accurately the true energetic efficiency. As the present results indicate, high estimates of one efficiency are usually associated with low estimates of another and vice versa. There is also the question whether it is acceptable in biological terms to separate the energy costs of maintenance from those of production. For example, Fig. 1 shows that as much as $30 \%$ of protein retention occurs at energy equilibrium, suggesting that a considerable portion of the energy cost of protein synthesis is included in the maintenance component. This may have contributed to some of the associations obtained in the present experiments. It also partly explains why theoretical values of $k_{P}$ are also higher than those determined experimentally. However, despite these deficiencies, the application of regression equations has proved useful in calculating the energy requirements of farm animals in different physiological states and under defined (and specified) conditions (Agricultural Research Council, 1981).

\section{REFERENCES}

Agricultural Research Council (1981). The Nutrient Requirements of Pigs, Slough: Commonwealth Agricultural Bureaux.

Agricultural Reasearch Council/Medical Research Council Committee (1974). Food and Nutrition Research Report of the Agricultural Research Council/Medical Research Council Committee. London: H.M. Stationery Office. 
Armstrong, D. G. (1969). In Handbuch de Tierernährung, vol. 1, p. 385 [W. Lenkeit, K. Breirem and E. Crasemann, editors]. Hamburg: Paul Parey.

Berschauer, F. (1977). Blutharnstoffkonzentration und Proteinverwertung beim Schwein. Diss. Hohenheimer Arb. H. 91. Stuttgart: E. Ulmer.

Berschauer, F., Close, W. H. \& Stephens, D. B. (1983). Br. J. Nutr. 49, 271.

Berschauer, F., Gaus, G. \& Menke, K. H. (1980). In Energy Metabolism, p. 101 [L. E. Mount, editor]. London: Butterworths.

Blair, R., Dent, J. B., English, P. R. \& Raeburn, J. R. (1969). J. agric. Sci., Camb. 72, 379.

Blaxter, K. L. (1962). The Energy Metabolism of Ruminants. London: Hutchinson Scientific and Technical.

Braude, R., Keal, H. D. \& Newport, M. J. (1977). Br. J. Nutr. 37, 187.

Brouwer, E. (1965). Publs Eur. Ass. Anim. Prod. no. 11, p. 441.

Campbell, R. G. (1977), Anim. Prod. 24, 69.

Carr, J. R., Boorman, K. N. \& Cole, D. J. A. (1977). Br. J. Nutr. 37, 143.

Close, W. H. (1978). Br. J. Nutr. 40, 433.

Close, W. H. \& Berschauer, F. (1981). Proc. Nutr. Soc. 40, 33 A.

Close, W. H. \& Mount, L. E. (1975). Br. J. Nutr. 34, 279.

Close, W. H. \& Mount, L. E. (1978). Br. J. Nutr. 40, 413.

Close, W. H., Mount, L. E. \& Brown, D. (1978). Br. J. Nutr. 40, 423.

Close, W. H. \& Stanier, M. W. (1980). In Energy Metabolism, p. 399 [L. E. Mount, editor]. London: Butterworths.

Close, W. H., Verstegen, M. W. A. \& Mount, L. E. (1973). Proc. Nutr. Soc. 32, 72 A.

Cooke, R., Lodge, G. A. \& Lewis, D. (1972). Anim. Prod. 14, 219.

Cromwell, G. L., Hays, V. W., Trujillo-Figueorn, V. \& Kemp, J. D. (1978). J. Anim. Sci. 47, 505.

Fowler, V. R., Fuller, M. F., Close, W. H.\& Whittemore, C. T. (1980). In Energy Metabolism, p. 151 [L. E. Mount, editor]. London: Butterworths.

Fuller, M. F. \& Boyne, A. W. (1971). Br. J. Nutr. 25, 259.

Fuller, M. F., English, P. R., Livingstone, R. M. \& Crofts, R. M. J. (1976). J. agric. Sci., Camb. 86, 7.

Gebhardt, G. \& Müller, H. (1971). Arch. Tierernähr. 21, 183.

Gray, R. \& McCracken, K. J (1974). Publs Eur. Ass. Anim. Prod. no. 14, p. 161.

Hoffmann, L., Jentsch, W., Klein, M. \& Schiemann, R. (1977). Arch Tierernähr. $27,421$.

Hoffmann, L., Jentsch, W. \& Schiemann, R. (1978). Arch. Tierernähr. 28, 273.

Holmes, C. W., Christensen, R., Carr, J. R. \& Pearson, G. (1980). In Energy Metabolism, p. 97 [L. E. Mount, editor]. London: Butterworths.

Houseman, R. W. \& McDonald, I. (1973). Anim. Prod. 17, 295.

Kellner, B. \& Kirchgessner, M. (1973). Arch. Tierernähr. 23, 3.

Kielanowski, J. (1965). Publs Eur. Ass. Anim. Prod. no. 11, p. 13.

Kielanowski, J. (1976). Publs Eur. Ass. Anim. Prod. no. 16, p. 207.

Kotarbinska, M. (1969). Wydaw. Wlasne Inst. Zootech. Wroclaw no. 238.

McCracken, K. J., Eddie, S. M. \& Stevenson, W. G. (1980). Br. J. Nutr. 43, 289.

Menke, K. H. (1979). Z. Tierphysiol. Tierernähr. Futtermittelk. 42, 173.

Millward, D. J., Garlick, P. J. \& Reeds, P. J. (1976). Proc. Nutr. Soc. 35, 339.

Mount, L. E. [editor] (1980). Energy Metabolism. London: Butterworths.

Müller, H. L. \& Kirchgessner, M. (1979). Z. Tierphysiol. Tierernähr. Futtermittelk. 42, 161.

Munro, H. N. (1964). In Mammalian Protein Metabolism, vol. 1, p. 381 [H. N. Munro and J. B. Allison, editors]. London: Academic Press.

Nielsen, A. J. (1971). Beretn. Forsogslab. no. 381.

Noblet, J. \& Close, W. H. (1980). In Energy Metabolism, p. 335 [L. E. Mount, editor]. London: Butterworths.

Oslage, H. J., Fliegel, H., Farries, F. E. \& Richter, K. (1966). Z. Tierphysiol. Tierernähr. Futtermittelk. $21,50$.

Piatkowski, B. \& Jung, H. (1966). Arch. Tierzucht. 9, 307.

Pullar, J. D. \& Webster, A. J. F. (1977). Br. J. Nutr. 37, 355.

Reeds, P. J., Cadenhead, A., Fuller, M. F., Lobley, G. E. \& McDonald, J. D. (1980). Br. J. Nutr. 43, 445.

Schiemann, R. (1963). Deutsche Akademie der. Landn. Sitzungsberichte. 12, 39.

Schiemann, R., Chudy, A. \& Herceg, O. (1961). Arch. Tierernähr. 11, 395.

Sharma, V. D., Young, L. G. \& Smith, G. C. (1971). Can. J. Anim. Sci. 51, 761.

Thorbek, G. (1975). Beretn. Forsogslab. no. 424.

Verstegen, M. W. A., Close, W. H., Start, I. B. \& Mount, L. E. (1973). Br. J. Nutr. 30, 21.

Webster, A. J. F. (1980). Livestock Prod. Sci. 7, 243. 